\title{
Storytelling as a Tool for Social Development and Community Outreach in Museums and Heritage Sites
}

Gehane Nabil

\begin{abstract}
Nowadays oral storytelling is frequently used as an effective method to reevaluate values and attitudes amongst different members of the communities in order to enhance social development and community outreach. In this regard, museums and heritage sites, which are the incarnation of human's stories throughout the time, may be considered among the best milieus to apply the art of storytelling and effectively utilize it for social development. This approach may contribute to convert museums and heritage sites to be among the best places for social-based informal learning.
\end{abstract}

This paper has 2 main objectives:

- To experiment the heritage storytelling as a basic tool to enhance social development among young communities.

- To measure the effectiveness of two storytelling techniques: The first is a participatory technique through which children hear the story from the storyteller then try to convert it into an improvised play, while in the other technique children are asked to learn a long script of a play by heart and to rehearse repeatedly.

To reach the two goals of the study, the researcher participated as a freelance storyteller in a summer camp which has taken place in a community center at a popular district in Historic Cairo, and in which she has applied the heritage storytelling technique on children from the local community.

To experiment the heritage storytelling as a basic tool to enhance social development among young communities, the researcher applied the focused or group interview method with framework of questions that allow for conversational style and additional questions. Through this method, the children expressed their impressions about the characters of the stories and the actions and reactions of those characters in the different phases of the stories.

To measure the effectiveness of the improvised and the non-improvised storytelling methods, the researcher applied the direct observation method through which she monitored the children's ability to convert the narrated story into an improvised play. She also observed the willingness of children to learn a long script by heart and to rehearse repeatedly in order to act in an excellent way and without mistakes at the final performance. Based on the observation method, the researcher evaluated the 2 storytelling methods and presented their advantages and disadvantages and ends by giving recommendation about the best practice of using the storytelling technique as a tool for social development.

\section{Keywords:}

Oral storytelling, dramatizing history, social development, community outreach. 


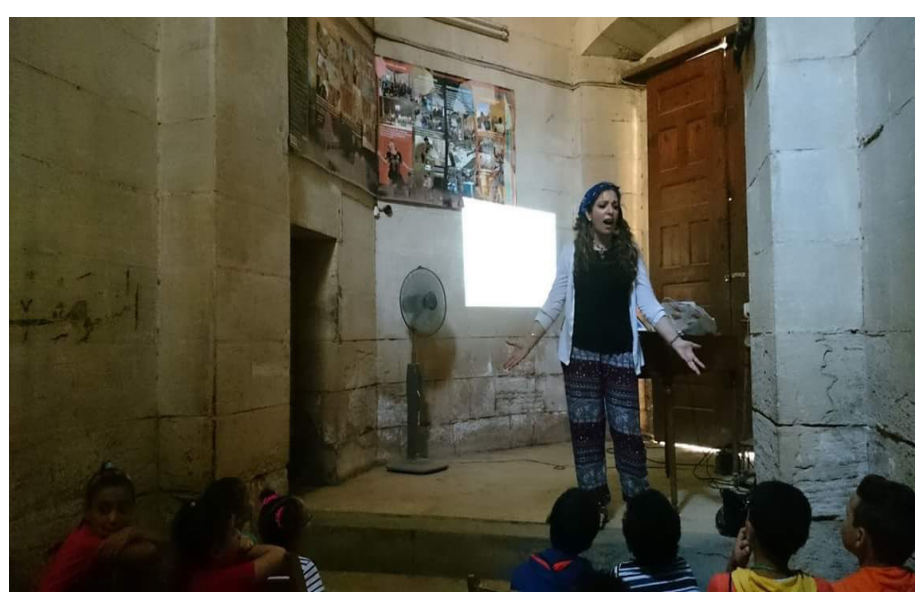

Fig. 1: Al Khalifa District, Atharlina Summer Camp, 2017

\section{Introduction}

The researcher's inspiration to tackle the topic of heritage storytelling from a social perspective was a personal experience with a 10-year-old boy. The researcher was invited to participate as a storyteller in an event held in a heritage site in old Cairo. And while she was in the midst of the session, one of the children interrupted her by asking spontaneously: "teacher, are you Muslim?!" The question surprised her but she decided to answer him normally and not to show any sign of discomfort and she replied quietly: "yes I am." Before she left the place, the very same child along with his younger sister came close to her and asked again: "Teacher, are all the female teachers who come to teach us here without wearing the veil Muslims?" At this point, the researcher decided to ask him: "And what if they are not?” Surprisingly, he quietly and normally retorted: "I don't like non- Muslims."

This was not just an incident; it is a very dangerous sign. This 10 -year-old boy had already done a classification for people on a religious basis and had decided to stop himself from socializing or loving anyone before ascertaining their religious affiliation.

This situation was like a turning point that made the researcher realize the urgent need to use the power of storytelling for a purpose that is wider and deeper than the current one of education and entertainment. The power of storytelling may be used as an effective tool for changing behaviors and enabling people to make better choices in their lives by listening to and understanding stories from history and being introduced to people who made choices that had an impact on history ${ }^{1}$.

Thus, the purpose of the research is to examine heritage storytelling as a technique of presenting historical events and highlighting human behaviors and choices that have shaped those events. This technique may improve students' capability to relate heritage to their daily lives and to the situations that they currently face and the choices that they currently make.

This approach may lead students to reconsider their choices towards negative moral values such as fanaticism, religious intolerance, selfishness, and biased judgment of others and to instill positive moral values like coexistence and the respect of differences. This approach may eventually lead to the social development and the community outreach that we are all aspiring to reach. 
In this regard, museums and heritage sites are the social hubs which may directly or indirectly host this new method:

- Directly through heritage storytelling performances in-situ (in museums and heritage sites

- Indirectly based on the concept of "taking storytelling outside the museum" ${ }^{2}$ through heritage storytelling performances which are related to the museums and heritage sites but may take place in schools, educational centers or other areas which lack the financial potential to organize field visits. The case study in this research was based on this indirect technique

\section{Importance of the Study}

From the researcher's readings and reviewing of literature, she noticed that many scholars have tackled heritage storytelling from an educational perspective and have focused on its role as an alternative to conventional education of history and social studies $^{3}$. Some other scholars have studied it from a social perspective and emphasized the idea of narrating factual or fictional stories- which are not necessarily related to history- to strengthen the moral positions and solidify positive values within the communities ${ }^{4}$. Others have shed light on using the storytelling technique in museums as a tool that offers an innovative experience for the visitor and enhances the emotional relationship between the visitor and the artifacts ${ }^{5}$.

However, using the museum as an educational and social hub in which history is dramatized and presented in an unconventional way in order to motivate children to learn more about their heritage and to reshape their choices by being introduced to the past and the choices of people who have shaped it, is not yet, to the best of the researcher's knowledge, tackled on a wide range. Thus, the researcher chose this "new" scope to be tackled in this paper.

After reviewing literature related to storytelling, the researcher presented her case study which consisted of her personal participation as a freelance storyteller in a summer camp which took place in one of the heritage sites at a popular district in historic Cairo, and in which she has applied the storytelling technique on children and youths from the local community. The researcher evaluated the effectiveness of the applied storytelling method to reach the goals of the study and ended by giving recommendations about using the storytelling technique as a tool for social development.

\section{Literature Review}

\section{The Power of Storytelling for Social Change}

In this research, which deals with heritage storytelling from a social perspective, the reviewing of literature mainly focuses on the previous studies that have tackled the topic of storytelling as a crucial tool of social awareness and community outreach. Storytelling is one of the oldest modes of human communication ${ }^{6}$. It is also one of the earliest methods of education by which knowledge, thoughts, and beliefs were transmitted from one generation to another ${ }^{7}$.

Brand and Donato cited in Watts ${ }^{8}$ shed light on storytelling as a strategy that may enhance social cohesion. They defined storytelling as "an art form that all human beings hold in common, in all places, and in all times. It is used in many ways, to educate, inspire, and entertain; to record historical events; and to transmit cultural customs”.

Davidson'also emphasized the importance of storytelling in educating and transmitting ethics and positive moral values to children: "Storytelling is a meaningful teaching strategy that can be utilized in nursing education to encourage the development of caring, empathy, compassion and to develop cultural competencies."

Many studies highlighted the power of storytelling and its strong impact on the audience. When a person hears a good story, very special parts in his brain are alerted; those parts which are responsible for emotions and feelings ${ }^{10}$. This converts his status from a simple receptor to an essential participant in the process and transforms him to a partner who shares the same emotions

\footnotetext{
${ }^{2}$ Leslie Bedford, "Storytelling: The real work of museums." Curator: the museum journal 44, no. 1 (January 2010): 32

${ }^{3}$ Julia E. Watts "Benefits of storytelling methodologies in fourth-and fifth-grade historical instruction.” Storytelling, Self, Society 4, no. 3 (2008).

${ }^{4}$ Donna Eder, Life lessons through storytelling: Children's exploration of ethics. (Indiana University Press, 2010).

${ }^{5}$ - Emily Johnsson, Telling Tales: A guide to developing effective storytelling programmes for museums. (Museums Hub, 2006).

${ }^{6}$ Emily Johnsson, Telling Tales: A guide to developing effective storytelling programmes for museums. (Museums Hub, 2006), 6 -

${ }^{7}$ Martha Hamilton and Mitch Weiss, Children tell stories: Teaching and using storytelling in the classroom. (Richard C Owen Pub, 2005), 1

${ }^{8}$ Julia E. Watts "Benefits of storytelling methodologies in fourth-and fifth-grade historical instruction.” Storytelling, Self, Society 4, no. 3 (2008): 189

${ }^{9}$ Michele R. Davidson, “A phenomenological evaluation: using storytelling as a primary teaching method.” Nurse Education in practice 4, no. 3 (2004): 188${ }^{10}$ Ffion Lindsay, The Seven Pillars of Storytelling: (Bristol, UK: Sparkol Books, 2015), 12.
} 
and is ready to share the same perceptions of the speaker. And this is the real magical, and at times manipulative, power of storytelling.

Other scholars focused on the same idea and suggested that storytelling helps people extract their inner feelings and express them easily and freely. As cited by Hamilton \& Weiss ${ }^{11}$, Paley reported that human beings are natural storytellers. From childhood they manage to put their feelings, their perceptions and even their fears in a storytelling context. A child may tell a story about family protection if he fears losing a family member, while the story would be about a mother taking care of her child to express the fear of being abandoned.

Moreover, in 2010 at Princeton University, an interesting empirical study was conducted by a group of neuroscientists to investigate the storytelling effect on the cognitive awareness of the audiences. To accomplish the experiment, they exposed a professional storyteller and his audiences to a MRI machine. During storytelling, the brain of the storyteller and his audiences showed closely equal activities in most areas. "Their brains effectively 'sync up" with one another in a phenomenon known as neuralcoupling". ${ }^{12}$

The power of storytelling also works, not only on the cognitive sense of the receptor but it also has a strong impact on his/her emotional state. When the popular clothing outlet John Lewis applied a new advertising campaign for Christmas, in which each video incorporated a human interest story, told through emotive filmmaking, the adverts became a viral hit. The ad campaign reached over 24 million viewers this year, and was no longer simple adverts for selling goods; they turned to be an annual event, awaited by people from all over the UK and abroad, and "a Part of the countdown to Christmas in the UK." 13

When the target audiences are children and youths, storytelling techniques have to be applied in a way that respects the major differences between children and grownups especially in visions and concerns. In her book Life Lessons through Storytelling ${ }^{14}$, Eder (2010) examined storytelling as a crucial tool which enables children to explore basic ethics that transform them into active participants in their community. She stated that children have far different concerns than adults. Accordingly, ethics have to be introduced to them in a different way through open-ended stories in which they may participate and be asked about their attitude if they were in the same situation as the characters.

In this regard, she presented a personal experience in which she told a story to two groups of children from the fifth grade. The story was about a beetle which decided to ruin the eggs of a mean eagle. Eder was surprised to see that many children skipped the main theme and characters of the story and focused on the marginalized part which is the eagle's eggs. Moreover, many children chose to identify with the eagle's eggs and decided to look for a way to save them from being destroyed by the beetle. In other words, children in this example took the side of the most innocent characters of the story and were very positive in their attempt to save them. From this experience, Eder deduced that the children's cognitive sense of ethics is totally different from the adults. They also have a far straighter sense of justice and strongly care for the wellbeing of others. These childish assets may be invested to instill positive moral values and strengthen ethics. In another example, while telling a story to another group, Eder saw that students expressed "highly ethical standards" and noticed their tendency to the idea of sacrificing one's life to save others.

\section{Heritage Storytelling-}

The reinterpretation of heritage through storytelling includes oral narrative of history and historical events or what is called the "dramatization of history." It may be a one-sided technique through which narration is fully done by the storyteller or a participatory technique where the audiences may take part and are converted from passive learners to active participants ${ }^{15}$. Many educational organizations are currently adapting an approach which aims to convert history into a transformative experience. "Facing History and Ourselves" is an international organization that aims "to promote student's historical understanding, critical thinking and socio-emotional learning." It works on reinterpreting historical events and enhancing

\footnotetext{
${ }^{11}$ Hamilton and Weiss, Children tell stories, 1.

${ }^{12}$ Lindsay, The Seven Pillars, 12.

${ }^{13}$ Ibid, 9 .

${ }^{14}$ Donna Eder, Life lessons through storytelling: Children's exploration of ethics. (Indiana University Press, 2010$), 17$.

${ }^{15}$ Julia E. Watts, "Benefits of storytelling methodologies in fourth-and fifth-grade historical instruction.” Storytelling, Self, Society 4, no. 3 (2008): 185.
} 
students to find certain connections between the narrated history and the moral choices that they make in their own lives. This approach may eventually lead students to reshape their points of view towards challenging social issues such as prejudice, racism and religious intolerance. ${ }^{16}$

In the framework of this initiative, an exhibition was held in many educational centers in different cities. The exhibition entitled "Choosing to Participate" targeted adolescents and aimed to narrate true stories from history and bring teenagers to imagine themselves in the same situation and encourage them to think about the action they would have taken if they were facing this situation. ${ }^{17}$

One of the most significant stories narrated during the exhibition was about the incident that happened in 1957 when a high school in the US called "Little Rock's Central High School" had to accept and integrate among its students nine African American students.

The narration of this story focused on one of the nine students called Elizabeth Eckford, a fifteen-year-old girl. The story was first narrated from her perspective and children were asked to put themselves in her shoes and imagine her first day as an African American encountering an angry crowd of white classmates. ${ }^{18}$

Then, the narrators tackled the story from the white students' perspective, whose choices were divided between bullying the girl, taking a passive action, or supporting and defending the girl against bullying. But the most striking part of the story was about one of the white students who had taken a passive action and said that later she regretted not being among the supporters. She regrets being one of the "Bystanders." 19

This story encompassed an indirect question to the audiences which is the following: If you ever encounter a similar situation and you witness a bullying incident happening to one of your classmates for the simple reason that he/she is different in some way, what choice would you make; to follow the crowd whether right or wrong, to be a bystander or to be a real support?

This is the trend in storytelling that our developing countries which face big challenges in many social issues, could apply. In this regard, our heritage is inexhaustible with stories which can motivate young people to re-evaluate actions and decisions which have been taken by the key persons in history and at the same time to re-evaluate their own choices if they are exposed to similar challenges.

\section{Heritage storytelling in Museums and Historical sites}

The question now is the following: Are museums and historical sites a favorable milieu for such an approach? According to the ICOM definition adopted by the 22nd General Assembly in Vienna, Austria on August 24th, 2007, museums are educational and entertaining organizations that mainly work for a community-based purpose.

Hence, the visitor of a museum or a historic site is a receptor with high expectations to learn more information during his visit. Besides, the visitor is open to getting this information in an innovative and informal way. In other words, the edutainment characteristic of the museum is what makes it a favorable milieu for innovative approaches. Bedford ${ }^{20}$ suggested that "Storytelling is a great strategy realizing the "constructivist museum," an environment where visitors of all ages and backgrounds are encouraged to create their own meaning and find the place, the intersection between the familiar and the unknown, where genuine learning occurs."

Moreover, it may have a far greater impact on the audiences upon hearing episodes of history in the same places where it occurred, such as in historic houses or heritage sites, or in museums while contemplating a piece dating back to the same historical period from which the story is narrated.

\footnotetext{
${ }^{16}$ https://www.facinghistory.org/about-us

${ }^{17}$ Bedford, "Storytelling: The real work of museums", 31

${ }^{18}$ Ibid, 31

${ }^{19}$ Facing History and Ourselves.Choosing to Participate.Facing History and Ourselves. 2009, 39-55

${ }^{20}$ Bedford, "Storytelling: The real work of museums", 33
} 
Bedford ${ }^{21}$ specified that "It makes sense that storytelling is appropriate to the work of a museum, for museums are storytellers. They exist because once upon a time some person or group believed there was a story worth telling, over and over, for generations to come."

\section{Case Study}

And here came the opportunity to experiment this new storytelling mode. This was in the framework of the summer camp where the researcher participated and which was organized by Atharlina initiative at Al Khalifa district.

What really characterizes $\mathrm{Al}$ Khalifa district is that the area in itself is a large heritage site. People live beside and around the monuments which are an essential part of the urban fabric of the place.

Moreover, people of Al Khalifa community are natural storytellers; their legacy is submerged in stories which are an awe inspiring mixture between history and legend. This makes that area a favorable milieu to apply different modes of storytelling.

\section{Target audience}

Children from the local community of al Khalifa divided into 2 age groups

7-10 years old.

$10-15$ years old.

Number of children in each group: About 15.

\section{Criteria of choosing the stories}

After setting the theme of the program (Storytelling for Social Change), the researcher began to select the stories not only according to their potential to entertain and historically educate the audiences but also according to their ability to make them reconsider their concepts and behavior towards particular topics.

In this regard, she attempted to choose stories which were in accordance with the selected theme and at the same time related to museums or heritage in the areas of $\mathrm{Al} \mathrm{Khalifa}$ and Sayeda Zaynab in order to emotionally connect the children to historic places at their neighborhood.

Thus the stories were selected from 2 heritage places:

- Stories from the Gayer Anderson Museum which is inside the area of Al- Khalifa

- Stories from the Beit el Sennary (a historic house situated at Al Sayeda Zaynab not far from Al Khalifa. The house is actually converted to a cultural center where many cultural events are taking place.

\section{Types of the Stories}

Previous studies divided stories into 2 types:

Fiction: based on the storyteller's own imagination or the imaginable product of other authors: Fairy tales, folklore and legends. Factual stories: Biography, autobiography, narration of historical or contemporary real events.

But due to the limitation of the research which focused on telling the stories of the two aforementioned places, the researcher extracted from the 2 places the stories which serve the theme of the research: (Stories for social change). For that purpose, the nature of the selected stories varied between factual and fictional stories.

However, the researcher sometimes used a technique that consisted of a mixture between fictional and factual stories which is also known as historical fiction. For instance, to narrate historical events related to the time of the French expedition in Egypt and the key persons who played a crucial role to shape those events, she put the real events in a framework of a fictional story and the historical figures turned to be the heroes of this historical fiction. The purpose of this mixture was to deliver the message in a vivid and engaging manner. 


\section{Designing the Program}

The program consisted of 6 workshops for each age group divided into 6 weeks (one workshop per week for each group).

\section{Age group 7-10years (Group A):}

Three short stories were selected from the Gayer Anderson Museum:

First story: (Gayer Anderson and the House Guard)

It is a biographical story about Gayer Anderson, the British officer and patron of the house, and his friendship with the old Egyptian guard of the house. This relationship started with a strong hatred and ended with an awesome friendship (moral: coexistence and acceptance of others)

Second Story: (The Benevolent Serpent)

Fictional story told by the guard of the house to Gayer Anderson about a family who once lived in the house of Kretlya at the same time with a family of serpents and how the relation between the 2 parties started by strong enmity and ended as well by friendship (everybody is important, do not despise the role of others).

Third story: (The Secret Chamber)

Fictional story told by the guard of the house to Gayer Anderson about another family who also lived in the house of Kretleya. The main character was the big brother Hassan who lived with his seven sisters and who always claimed to be poor in spite of a magic well which gave him every morning a bucket of gold. The story showed how the magic disappeared and the well stopped giving buckets of gold to the greedy man whose sisters and wife eventually discovered the truth and abandoned him not for his poverty but for his greed and dishonesty (moral: Being honest and generous is your way to live happily with others).

\section{Age Group 10-15 years (Group B)}

A long story from the Beit el Sennary historic house (This House belongs to us).

Nature of the story: Fictional history in which 4 figures from history resurrected and were arguing and disputing about the right to own the house while a young boy from our era decided to be the judge and hear from each of them his story and why he claimed to have the right to own the house. The young boy ended up by suggesting that the house belongs to all of them as each and every one has contributed to shape the historical events related to the house and its era (moral: coexistence).

\section{Action Plan}

First phase: (Let's tell stories): Duration 3 weeks

The same activities were offered to the 2 age groups and the activities consisted of:

1. Experience the story: The children listened to the stories accompanied by a data show displaying pictures of the sequential events.

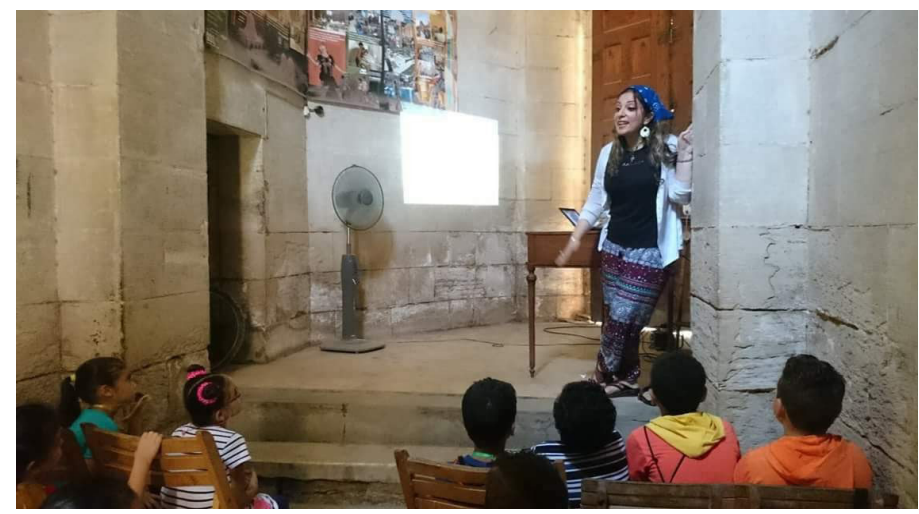

Fig. 2: Experience the Story

2. Your turn to tell the story: Recalling the events and key persons of each of the stories by encouraging some of the children each in his turn to tell the story by improvisation, while the others agreed on a sign to do to express their agreement and disagreement to what the narrators say. 


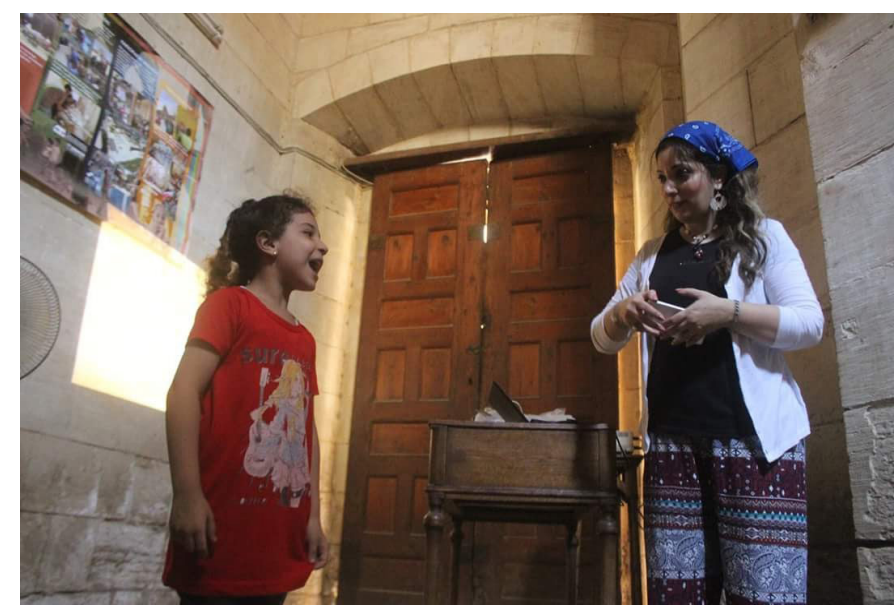

Fig. 3: Your turn to tell the story (Group A)

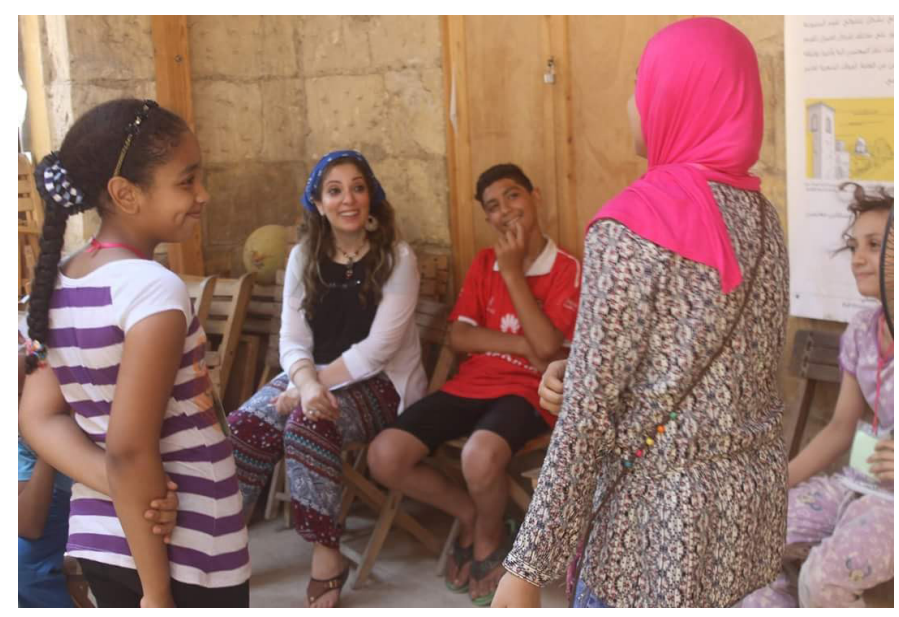

Fig. 4: Your turn to tell the story (Group B)

3. Let's try to act: Children were divided into 2 or 3 groups and an acting competition was held between the groups. The children were asked to use the masks which represent the different characters of the stories. 


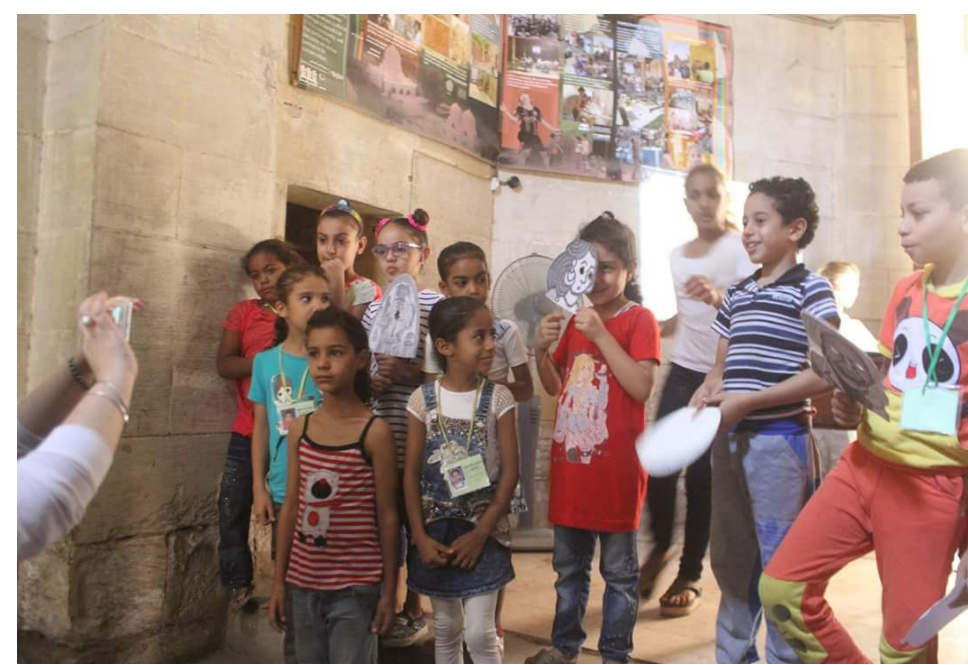

Fig. 5: Let's try to act (Group A)

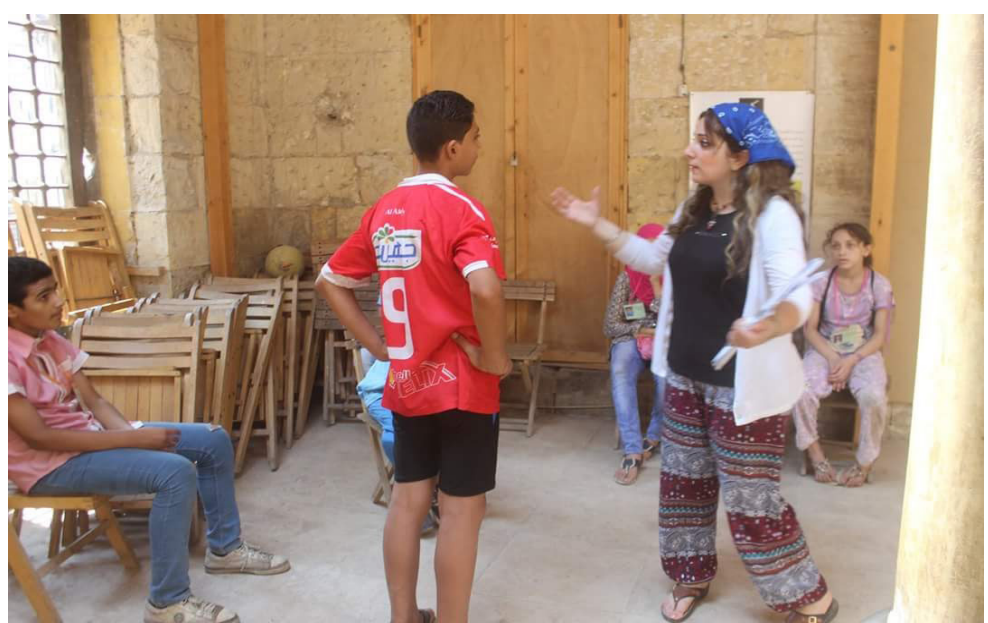

Figure 6: Let's try to act (Group B)

\section{Second Phase: (Let's Train and Perform) Duration three weeks}

In this phase, the researcher attempted to examine 2 methods to train the children for a final performance in which they will act the learned story on stage in front of a real public (which will be their parents).

For the first age group 7-10 (Group A), she applied the method of improvisation; no script was written and every child was asked to recall the events of the story and to create and improvise his own script. 


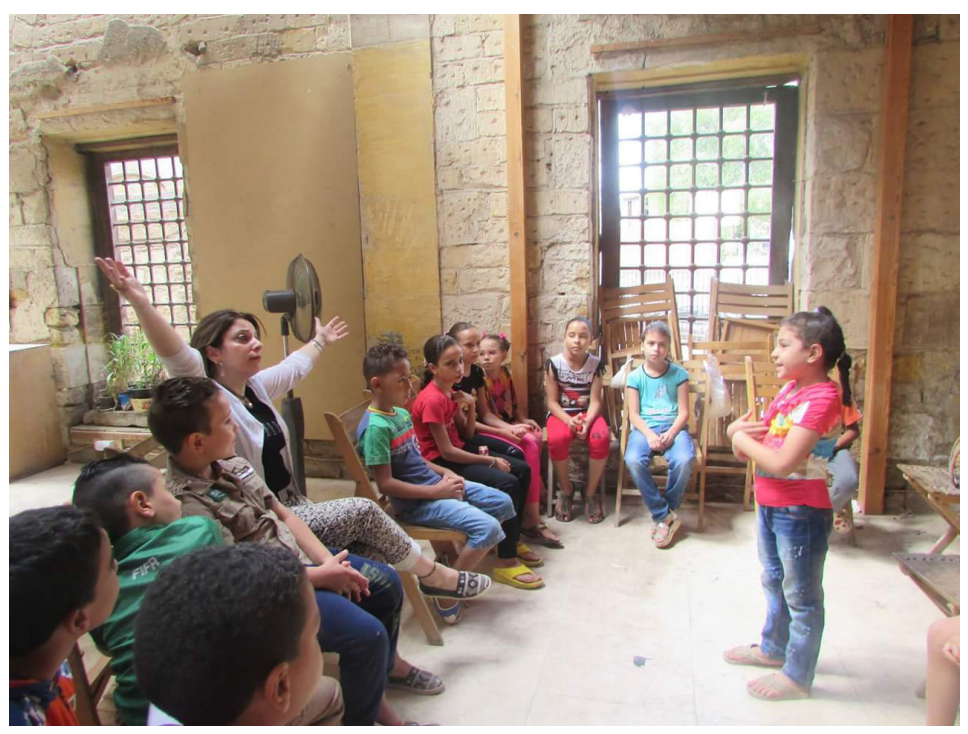

Fig. 7: Let's train and perform (Group A)

While for the second age group 10-15 (Group B), a long script had been written and children were asked to learn it by heart and to rehearse repeatedly in order to act in an excellent way and without mistakes at the final performance.

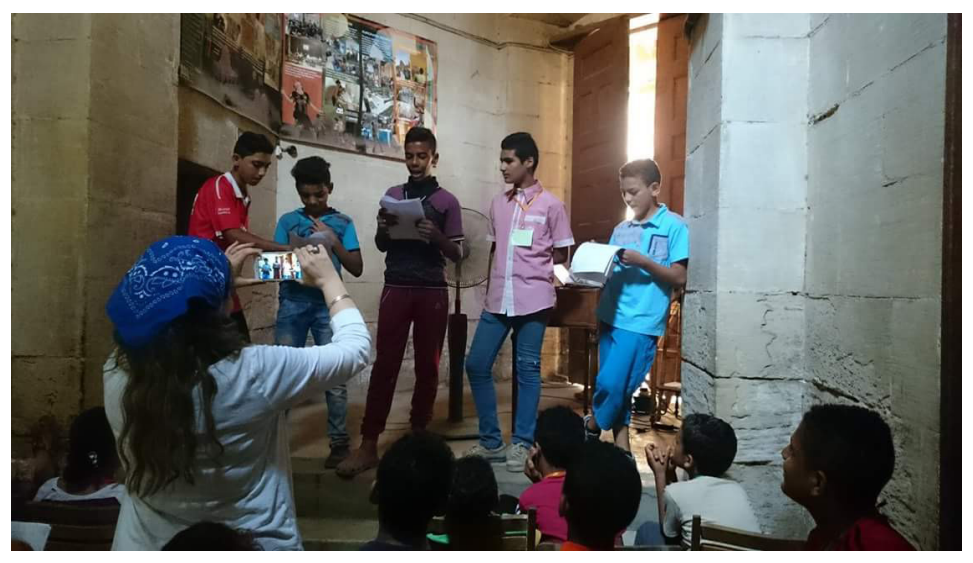

Fig. 8: Let's train and perform (Group B)

\section{Results:}

The first phase of the program (Let's Tell Stories) is evaluated in order to measure the effectiveness of the narrated stories and their ability to enhance the children to think critically about the behavior of the characters of the stories:

After listening to the stories in the first phase of the program, and in order to measure their impact on children, the researcher applied the focused interview technique with framework of questions that allowed for conversational style and additional questions. She asked a set of questions to find out what the children have understood from the story and other questions concerning their opinions about some decisions taken by the characters of the stories, and what they would decide to do if they were in the same situation of the characters. Through this method, the children expressed their impressions about the characters of the stories and their actions in the different phases and incidents of the stories: 
Group A:

First story (Gayer Anderson and the House Guard):

After narrating the story, the storyteller asked the children about the reason of the strong friendship that occurred between the British officer and his house guard. 13 children (about $90 \%$ of the children) stated that the reason of this friendship was that the guard narrated interesting stories to the officer, while 2 children (about10\%) thought that the nice relationship between the two guys emerged when they decided to love and accept each other.

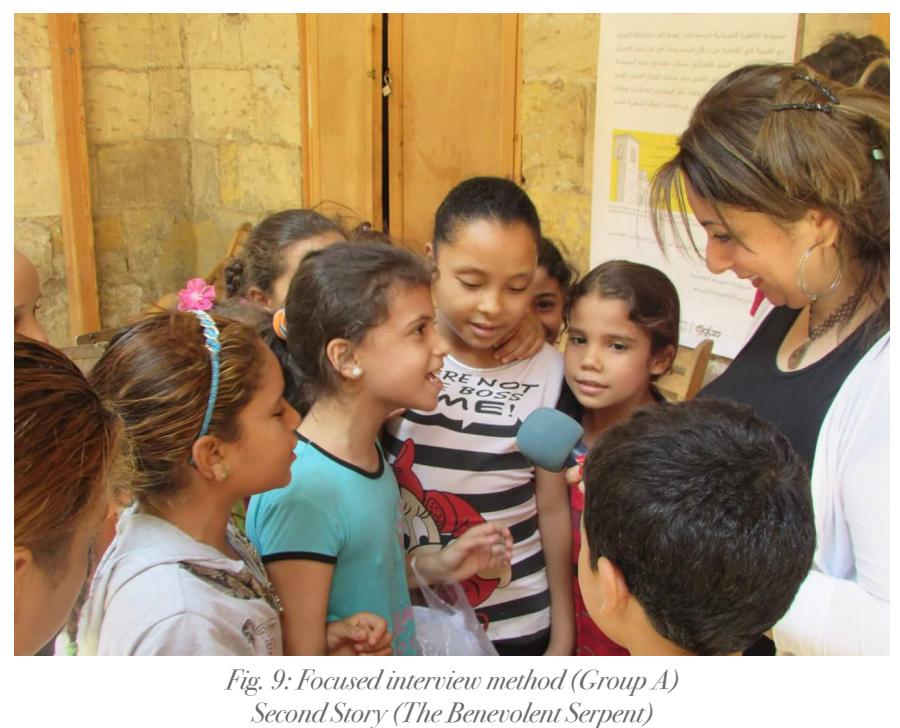

The storyteller asked the children about what they liked most and what they learned from the story. 12 children (about80\%) agreed that they liked the friendship between the owner of the house and the serpent because they help and respect each other. While 3 children $(20 \%)$ stated that what they liked was that humans have to be friendly with animals.

Third story (The Secret Chamber).

The storyteller asked the children about the reason why the wife and sisters of Hassan abandoned him after discovering the story of the gold and the magic well. 14 children (about 99\%) of the children had the similar answers in which they stated that Hassan was not only greedy and stingy, but also a liar who deserves to stay lonely for the rest of his life.

Group B

After narrating the story "This House belongs to us" to group B, the researcher asked the children about the character in the story that had the right to own the house, and each one was asked to be identified with the child who was judging between the adversaries. Five children from the fifteen (about 30\%) suggested that all the characters may coexist and peacefully live together in the same house, which was the intended moral of the story. But what was really interesting is that 10 children (about $70 \%$ of the total number of the children) stated that El-Sennary spent a lot of money to build the house, making him the rightful owner of the house. By doing so, the children themselves added a new moral to the story. They believed that giving the house to its original owner was the fair and just thing to do. Somehow, the kids were able to explain a value that the researcher hadn't intended to explain to them, and had their own solution to the story; one that she hadn't even considered.

\section{Analysis}

The pre-set theme applied by the storyteller was partially reached by the two groups of children. However, the children were very creative in adding many other themes that were sometimes more logical than the theme set by the storyteller. In other words, the storytelling technique proved its ability to enhance children to think critically about the characters of the stories and their choices and attitudes throughout the incidents of the stories. 


\section{Evaluation of the second phase of the program and the two storytelling techniques applied in it}

To measure the effectiveness of the improvised and non-improvised storytelling methods, the researcher applied the direct observation method through which she monitored the behavior and attitude of the children of group A towards the presented stories, their responses after hearing each of the stories and their ability to convert it into an improvised play. She also observed the willingness of children of group B to learn a long script by heart and to rehearse repeatedly in order to act in an excellent way and without mistakes at the final performance.

\section{Analysis}

\section{Advantages of the improvisation method:}

- Improvisation is a perfect arena for children to create, to express their feelings and their understandings of the stories that they heard.

- It is also the best way to indirectly let the children express their opinion and put themselves in the shoes of the characters of the story.

\section{Disadvantage of this method:}

- With the absence of a written script, children sometimes lost concentration and lacked harmony among each other. Accordingly this method needs much more time to do a lot of rehearsals in order to avoid this problem.

\section{Advantages of the method relying on learning the script by heart:}

It is a challenging method that makes the children feel capable to learn and perform a long and not easy script.

- Children were in great harmony during the final performance because everyone knows what to say and when the turn of his colleague will be.

- The result is a perfect final performance without any risks or mistakes; this made the children satisfied and less panicked when facing the audience.

- The method needs less time and fewer rehearsals because children were asked to learn the script at home and this saved a lot of time during the workshops.

\section{Disadvantages of this method:}

This method does not give the chance for children to create or improvise. It also does not leave them room to express their feelings or their point of view or to put themselves in the shoes of the characters of the story.

\section{Limitations}

Applying such a program which consists of experiencing and performing stories needed more than 6 weeks. Furthermore, the original plan was for the program to end with a visit to the places on which the narrated stories were based. Unfortunately, due to the short time of the camp, this visit was not implemented. Accordingly, the researcher needs to re-apply the same method on an expanded period of time which is estimated to be 3 months. The researcher was too ambitious to think that she can moderate each workshop without assistance. But she eventually realized that two facilitators in addition to the main instructor for each workshop were mostly needed to efficiently achieve the program.

Due to the nature of Al-Khalifa district where the camp had taken place, the formation of unchangeable groups of children with total commitment to attend the workshops weekly was difficult to implement. Thus, the researcher constantly had to take the time to keep the new members updated by retelling the stories and repeatedly explaining what they had to do. However, this was a good opportunity to give this task to the children who are committed to attending. These children showed great willingness to cooperate and a deep understanding of the stories and the workshop. 


\section{Conclusion and Recommendations}

Storytelling for social change is a promising mode which needs to be experimented on a wider range.

We possess in Egypt all the assets that make the application of such a method possible, i.e. museums and heritage sites and a legacy of endless stories that are a raw material from which we can extract unlimited moral values. In addition, the human element of Egyptian children is the fertile soil which is ready to be planted by more positive values for the wellbeing of a new Egypt.

Hence, the researcher appeals all those who are responsible for the social development of Egyptian society to start to expand the use of storytelling as an efficient tool for a qualitative social transition for future generations. And as Barbara Hardy ${ }^{22}$ once wrote: "We dream in narrative, day-dream in narrative, remember, anticipate, hope, despair, believe, doubt, plan, revise, criticize, construct, gossip, learn, hate and love by narrative."

\section{Bibliography}

Bedford Leslie, "Storytelling: The real work of museums." Curator: the museum journal 44, no. 1 (January 2010)

Davidson Michele R. Davidson, “A phenomenological evaluation: using storytelling as a primary teaching method.” Nurse Education in practice 4, no. 3 (2004)

Eder Donna, Life lessons through storytelling: Children's exploration of ethics. (Indiana University Press, 2010)

Facing History and Ourselves.Choosing to Participate. https://www.facinghistory.org/resource library?search=Choosing\%20to\%20Participate

Hamilton Martha and Weiss Mitch, Children tell stories: Teaching and using storytelling in the classroom. (Richard C Owen Pub, 2005)

Hardy, Barbara. “Towards a Poetics of Fiction. An Approach through Narrative.” In The Coo' Web, Edited by Margaret Meek, Aidan Warlow, and Griselda Barton. New York: Atheneum, 1978.

https://www.facinghistory.org/about-us Johnsson Emily, Telling Tales: A guide to developing effective storytelling programmes for museums. (Museums Hub, 2006)

Lindsay Ffion, The Seven Pillars of Storytelling: (Bristol, UK: Sparkol Books, 2015)

Watts Julia E. "Benefits of storytelling methodologies in fourth-and fifth-grade historical instruction." Storytelling, Self, Society 4 , no. 3 (2008)

\footnotetext{
${ }^{22}$ Barbara Hardy, “Towards a Poetics of Fiction. An Approach through Narrative.” In The Coo' Web, Edited by Margaret Meek, Aidan Warlow,
} and Griselda Barton. New York: Atheneum, 1978 